University of Wollongong

Research Online

Faculty of Engineering and Information

Faculty of Engineering and Information

Sciences - Papers: Part A

Sciences

$1-1-2013$

\title{
Ground improvement at the Port of Brisbane, Australia using vertical drains and vacuum assisted preloading
}

Buddhima Indraratna

University of Wollongong, indra@uow.edu.au

Cholachat Rujikiatkamjorn

University of Wollongong, cholacha@uow.edu.au

A S. Balasubramaniam

Griffith University

Follow this and additional works at: https://ro.uow.edu.au/eispapers

Part of the Engineering Commons, and the Science and Technology Studies Commons

Research Online is the open access institutional repository for the University of Wollongong. For further information contact the UOW Library: research-pubs@uow.edu.au 


\title{
Ground improvement at the Port of Brisbane, Australia using vertical drains and vacuum assisted preloading
}

\begin{abstract}
Soft clays in coastal areas have low shear strength and high compressibility. Thus construction activities for infrastructure developments in these deposits often pose geotechnical problems due to large time dependent settlements and lateral movements. Ground improvement techniques are adopted to reduce the water content of the soft clays by preloading techniques with vertical drains. Depending on the magnitude of the surcharge used substantial immediate settlement with lateral movements can takes place during preloading. This in tum causes stability problems in the loaded areas. The use of vacuum assisted preloading has now become a popular method in Australia where substantial loads need to be carried out to meet a desired rate of settlement and mitigate undrained failure. To assist the vacuum propagation to significant depths, vertical drains are used in conjunction. At the Port of Brisbane, Australia, vacuum assisted surcharge pre loading and conventional surcharge preloading schemes were used to reduce the time required for consolidation and long term settlement in soft Holocene clays. The design of the combined vacuum and surcharge fill system and construction of the embankment are described in this paper. A comparison made on the performance of a combined vacuum surcharge loading system with a standard surcharge fill highlights the clear benefits of vacuum consolidation. Field monitoring data on surface and sub-surface settlements, pore pressures and lateral movements on test embankments performed during construction are presented. An analytical solution for radial consolidation that considers both time-dependent surcharge loading and vacuum pressure to predict the settlement and associated excess pore pressures in soft clay deposits is also proposed.
\end{abstract}

\section{Keywords}

australia, brisbane, port, drains, improvement, vacuum, ground, vertical, preloading, assisted

\section{Disciplines}

Engineering | Science and Technology Studies

\section{Publication Details}

Indraratna, B., Rujikiatkamjorn, C. \& Balasubramaniam, A. S. (2013). Ground improvement at the Port of Brisbane, Australia using vertical drains and vacuum assisted preloading. In A. W. Stuedlein \& B. R. Christopher (Eds.), Sound geotechnical research to practice : honoring Robert D. Holtz II (pp. 540-550). Reston: American Society of Civil Engineers. 


\title{
Ground Improvement at the Port of Brisbane, Australia Using Vertical Drains and Vacuum Assisted Preloading
}

\author{
Buddhima Indraratna $^{1}$, Cholachat Rujikiatkamjorn ${ }^{2}$ and A.S. Balasubramaniam ${ }^{3}$ \\ ${ }^{1}$ Professor and Head, School of Civil, Mining and Environmental Engineering, Faculty of Engineering, \\ University of Wollongong, Wollongong, NSW 2522, Australia <indra@uow.edu.au> \\ ${ }^{2}$ Senior Lecturer, Centre for Geomechanics and Railway Engineering, School of Civil, Mining and \\ Environmental Engineering Faculty of Engineering, University of Wollongong, Wollongong, \\ NSW 2522, Australia. \\ ${ }^{2}$ Adjunct Professor, School of Civil Engineering Griffith University, Gold Coast, Queensland, \\ Australia
}

\begin{abstract}
Soft clays in coastal areas have low shear strength and high compressibility. Thus construction activities for infrastructure developments in these deposits often pose geotechnical problems due to large time dependent settlements and lateral movements. Ground improvement techniques are adopted to reduce the water content of the soft clays by preloading techniques with vertical drains. Depending on the magnitude of the surcharge used substantial immediate settlement with lateral movements can takes place during preloading. This in turn causes stability problems in the loaded areas. The use of vacuum assisted preloading has now become a popular method in Australia where substantial loads need to be carried out to meet a desired rate of settlement and mitigate undrained failure. To assist the vacuum propagation to significant depths, vertical drains are used in conjunction. At the Port of Brisbane, Australia, vacuum assisted surcharge preloading and conventional surcharge preloading schemes were used to reduce the time required for consolidation and long term settlement in soft Holocene clays. The design of the combined vacuum and surcharge fill system and construction of the embankment are described in this paper. A comparison made on the performance of a combined vacuum surcharge loading system with a standard surcharge fill highlights the clear benefits of vacuum consolidation. Field monitoring data on surface and sub-surface settlements, pore pressures and lateral movements on test embankments performed during construction are presented. An analytical solution for radial consolidation that considers both time-dependent surcharge loading and vacuum pressure to predict the settlement and associated excess pore pressures in soft clay deposits is also proposed.
\end{abstract}

\section{INTRODUCTION}

Soft clays in the coastal regions of Australia have low shear strength and high compressibility posing challenging geotechnical problems in infra-structure 
developments. Bjerrum (1973) studied in detail the stability of structures built in soft clay deposits. The need for suitable ground improvement techniques in such week soils to prevent detrimental effects on overlying structures due to excessive settlements and lateral movements has been emphasized by Holtz et al (1991) and Indraratna and Redana (2000) among others. A system of vertical drains with a combined vacuum and surcharge preloading is found to be an effective ground improvement technique for promoting the radial flow of water and accelerating consolidation of such soft soils. Thanks to the progress made over the past decade through rigorous analytical and numerical analysis, the behaviour of soft clay stabilised with vertical drains and vacuum pressure can now be predicted with acceptable accuracy. Mohamedelhassan and Shang (2002) proposed an analytical solution for one-dimensional consolidation with a vacuum application. Indraratna et al. (2005), Geng et al. (2011) extended the unit cell radial consolidation theory for vacuum application while considering the loss of vacuum along the length of the drain.

In this paper, a comparison is made of the performance of test embankments constructed in areas wherein vacuum- assisted vertical drain consolidation is used with embankment performance in areas in which non-vacuum assisted vertical drain consolidation is used at the Port of Brisbane Site in Queensland, Australia. The Port of Brisbane is located between the Brisbane River and Fisherman Islands (Indraratna et al. 2011) and is considered to be Australia's third largest container port. As the demand in trading activities has increased, a new area (235ha) adjoining the current port facilities is being reclaimed to increase the available land and provide additional berths for cargo and container handling (Fig. 1). In this reclaimed area, the soil profile consists of a very soft layer of clay over $30 \mathrm{~m}$ thick, with undrained shear strength near the surface that is generally below $15 \mathrm{kPa}$. The dredged mud used for reclamation has significantly lower shear strength, depending on the time of placement and duration of the preloading period. Without any improvement to the pre-construction soil, consolidation would take more than 5 decades, while under the required service load there would be excessive vertical settlements of $2.5-4.0 \mathrm{~m}$. Therefore, vacuum consolidation with prefabricated vertical drains (PVDs) was used to accelerate consolidation, curtail lateral deformation, and minimise adverse environmental effects on the adjacent area (Moreton Bay Marine Park) (Austress Menard 2008).

Several full scale test embankments were constructed at the POB site and observations were made on settlements, excess pore pressures, and lateral displacements. The effects of drain spacing, drain type, vacuum pressure and the degree of consolidation observed are discuss herein. Analytical solutions for radial consolidation that consider both time-dependent surcharge loading and vacuum pressure are proposed to predict the settlement and associated excess pore pressure.

Chu et al. (2000) and Chai et al. (2005) described the application of vacuum preloading with PVDs, where suction can be transmitted deep into the subsoil via a system of PVDs. Moreover, for a desired degree of consolidation (usually $>95 \%$ ), the 
required height of the surcharge fill may be lowered by several metres (Indraratna et al. 2005), or the number of construction stages can be reduced (Yan and Chu 2003; Rujikiatkamjorn et al. 2008). Consolidation increases the stiffness and shear strength of the soil and decreases the corresponding post-construction settlement, which reduces the risk of differential settlement that can affect the overlying infrastructure (Shang et al. 1998).

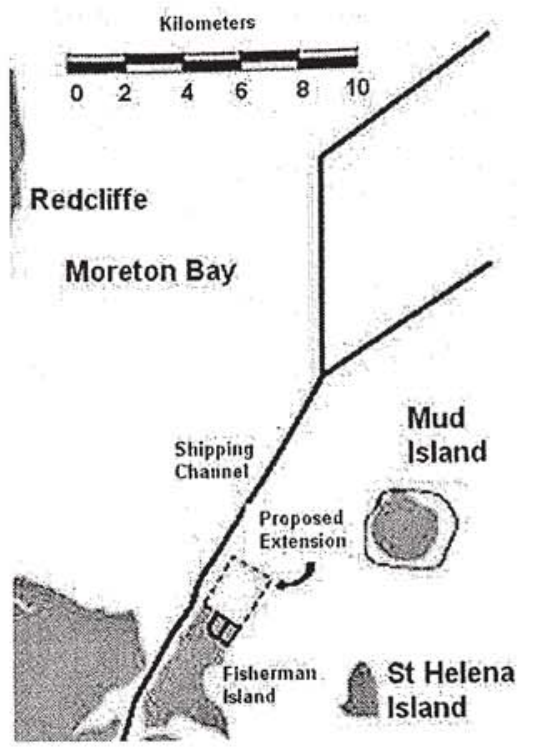

FIG 1. Map of the proposed extension at the Port of Brisbane (adopted from the Port of Brisbane Corporation 2009)

\section{GENERAL DESCRIPTION OF THE EMBANKMENT CHARACTERISTICS AND SITE CONDITIONS}

Beneath the dredged mud (at the site) was an approximately 2-3 metre thick layer of upper Holocene sand over a layer of Holocene clay $(6-25 \mathrm{~m})$, that had a very low shear strength (Ameratunga et al. 2010). The Holocene layer overlies a Pleistocene deposit comprised of highly over-consolidated stiff clay. Site investigations such as cone penetration/piezocone tests, pore water pressure dissipation tests, boreholes, field vane shear tests, and oedometer tests were carried out to evaluate the associated consolidation and strength parameters. The profile of the soil and its corresponding properties, where the groundwater level is $3.5 \mathrm{~m}$ above the reference level, are shown in Fig. 2. In general, the water contents were at or beyond their liquid limits. Vane tests conducted in the field indicated that the undrained shear strength of the dredged mud and Holocene clays varied from 5 to $60 \mathrm{kPa}$, and the compression index $\left(C_{c}\right)$ varied from $0.1-1.0$. The coefficient of consolidation in a vertical direction $\left(c_{v}\right)$ was approximately the same as that in a horizontal direction $\left(c_{h}\right)$ for the totally remoulded layer of dredged mud, while $c_{v} / c_{h}$ is about 2 for the layer of Holocene clay.

To compare the performance of the vacuum system with the non-vacuum system (PVD and surcharge load), a trial area (S3A) presented in Fig. 3 was divided into small areas (a) WD1-WD5 (Non-vacuum areas) and (b) VC1-VC2 (Vacuum areas). They ranged from 1500 to $11000 \mathrm{~m}^{2}$. After the reclaimed mud had drained or dried, it 
was capped off with a few metres of dredged sand to act as a working platform for the PVD installation rigs, while providing a drainage layer for the vacuum system.

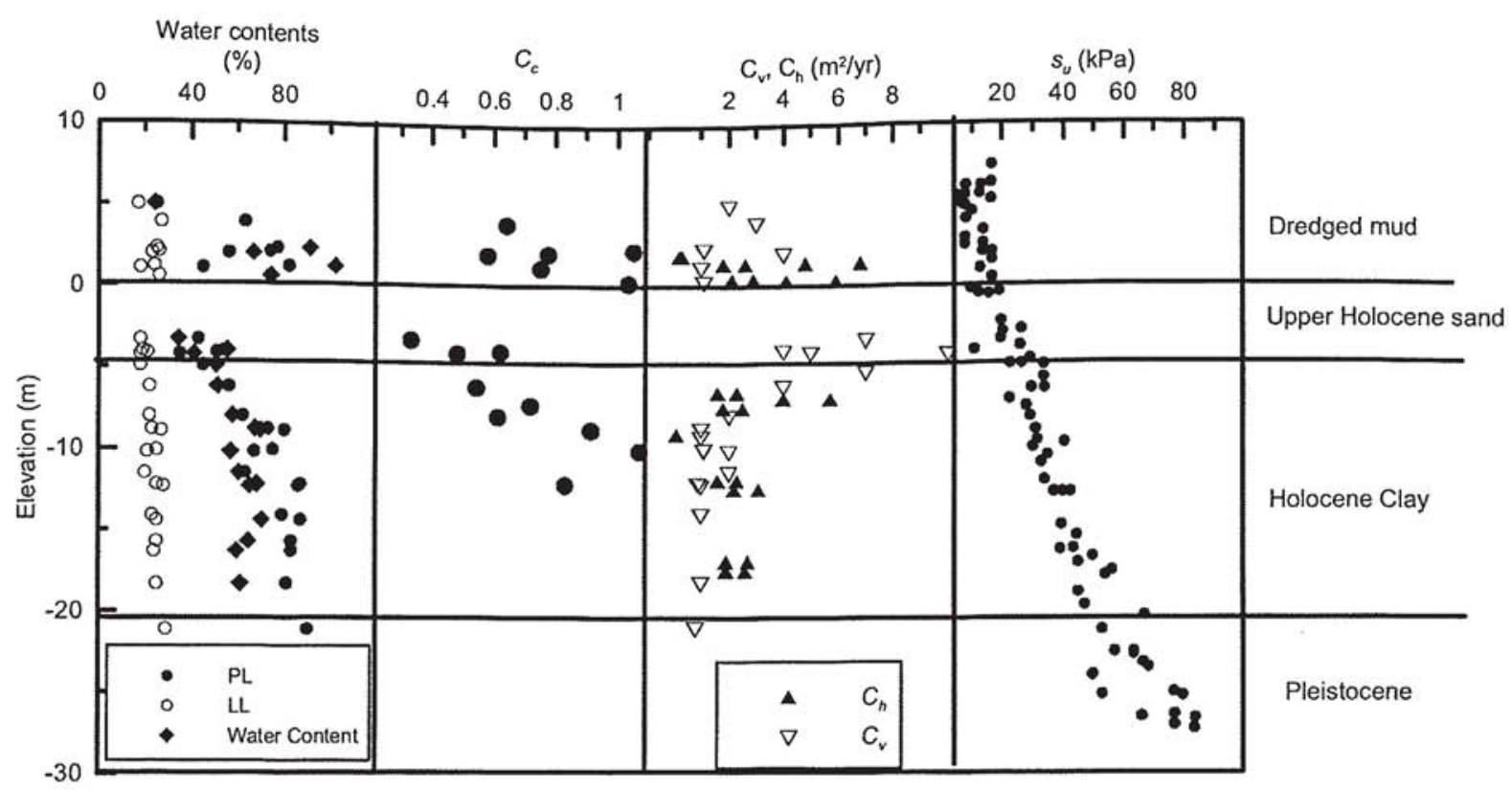

FIG 2. Soil properties and profile at S3A, Port of Brisbane

Two preloading techniques, including a conventional surcharge preloading system and a membrane-type vacuum consolidation system, both applied to PVDs, were used to minimise long term settlement due to the service load. A surcharge preloading system was used in the WD1-WD5 areas, but in the VC1 and VC2 areas that are close to a Marine Park, a combined vacuum preloading approach was used because it would curtail outward lateral displacement and minimise any adverse environmental effects on the marine habitats. Stringent long term settlement criteria were considered for the design and construction of fill embankments and vacuum application, i.e. a service load of $15-25 \mathrm{kPa}$ with a maximum residual settlement of less than $0.25 \mathrm{~m}$ over 20 years. The heights of the surcharge embankments were from $3.0 \mathrm{~m}$ to $9.0 \mathrm{~m}$, depending on the thickness of the clay. Based on the design criteria, Table 1 shows the characteristics of the PVD and types of treatment applied to each section. In the non-vacuum areas, circular and band shaped PVDs were installed in a square pattern at a spacing that varied between $1.1-1.3 \mathrm{~m}$. The lengths of the drains varied from $8 \mathrm{~m}$ to $28.7 \mathrm{~m}$, depending on the thickness of the clay. Wick drains (Band Drain Type-A and Band Drain Type-B) were typically $100 \mathrm{~mm} \times 4 \mathrm{~mm}$, while the circular drains had an internal diameter of $34 \mathrm{~mm}$.

In the vacuum area, circular PVDs were installed $1.2 \mathrm{~m}$ apart in a square pattern, in conjunction with an airtight membrane and horizontal perforated pipes connected to the pumps. The boundary of the membrane was buried in a flooded soil-bentonite peripheral trench to ensure absolute air tightness during operation (Berthier et al, 2009). The actual suction varied from $-60 \mathrm{kPa}$ to $-75 \mathrm{kPa}$, and no air leaks were encountered when the vacuum was applied, proving that the membrane provided an intact seal. A 'leak test' was performed at every welded membrane joint, to ensure a perfect seal. A cut-off wall was installed at the boundary of the embankment to 
ensure that the suction propagated along the surface of the soil and down the PVDs, within an airtight domain.

TABLE 1. PVD characteristics, maximum thickness of clay and treatment scheme.

\begin{tabular}{|c|c|c|c|c|c|c|}
\hline Area & Drain type & $\begin{array}{l}\text { Maximum } \\
\text { drain } \\
\text { length }(\mathrm{m})\end{array}$ & $\begin{array}{l}\text { Drain } \\
\text { spacing } \\
\text { (m) }\end{array}$ & $\begin{array}{c}\text { Maximum } \\
\text { Clay } \\
\text { thickness } \\
(\mathrm{m}) \\
\end{array}$ & $\begin{array}{c}\text { Total } \\
\text { fill } \\
\text { height } \\
\text { (m) } \\
\end{array}$ & $\begin{array}{l}\text { Treatment } \\
\text { scheme }\end{array}$ \\
\hline WD1 & Circular drains & 18.5 & 1.1 & 15.5 & 5.2 & Surcharge \\
\hline WD2 & Circular drains & 27.5 & 1.3 & 23.5 & $7-7.2$ & Surcharge \\
\hline WD3 & $\begin{array}{l}\text { Band drains } \\
\text { Type-A }\end{array}$ & 23.5 & 1.1 & 17.0 & $4.3-4.6$ & Surcharge \\
\hline WD4 & $\begin{array}{l}\text { Band drains } \\
\text { Type-A }\end{array}$ & 28.7 & 1.3 & 24.5 & 6.1 & Surcharge \\
\hline WD5A & $\begin{array}{l}\text { Band drains } \\
\text { Type-B }\end{array}$ & 8.0 & 1.2 & 8.0 & 3.3 & Surcharge \\
\hline WD5B & $\begin{array}{l}\text { Band drains } \\
\text { Type-B }\end{array}$ & 13.5 & 1.1 & 9.5 & 5.5 & Surcharge \\
\hline $\mathrm{VC1}$ & Circular drains & 26.5 & 1.2 & 21.0 & 3.2 & $\begin{array}{c}\text { Surcharge+ } \\
70 \mathrm{kPa} \\
\text { vacuum }\end{array}$ \\
\hline $\mathrm{VC} 2$ & Circular drains & 22.5 & 1.2 & 18.5 & 2.8 & $\begin{array}{c}\text { Surcharge+ } \\
70 \mathrm{kPa} \\
\text { vacuum }\end{array}$ \\
\hline
\end{tabular}

\section{ANALYSIS OF FIELD DATA}

The measured vertical displacements and excess pore pressures, together with the construction stages of the embankments, are shown in Fig. 4. The settlement curves for all the sites were compared, and in every case, settlement occurred faster at the initial consolidation stage. The magnitude of ultimate settlement depends on the thickness of the clay and the load on the embankment. While minimum settlement occurred in the WD5A area where the layer of clay was relatively thin, maximum settlement occurred in the WD4 area where the clay was thickest. Table 2 shows a summary of the settlement-based degree of consolidation (DOC). The DOC achieved in VC2 was greater than in the surcharge only areas. There is no direct relationship between the types of drains and the DOC according to this settlement - based analysis. Some relevant observations are summarised below although the limitations stemming from comparing different sections with different soil profiles and surcharge fill heights are recognised.

(i) Both WD1 and WD3 have a similar thickness of clay at 14-15m, and similar fill heights at 4.5-5.2m (for a relatively close drain spacing $(1.1 \mathrm{~m})$. All three types of drains performed equally well based on the DOC values, 
(ii) Circular drains and Band Drain-A performed equally well in areas WD2 and WD4, respectively, for an increased spacing of $1.3 \mathrm{~m}$.

(iii) When the spacing of Band Drain Type-A was increased from 1.1m (WD3) to $1.3 \mathrm{~m}$ (WD4), the DOCs attained after 400 days were similar. The performance similarity may result from the smear effects becoming increasingly more significant at closer spacing and the otherwise expected increase in consolidation with closer drain spacing being compromised.

(iv) Band Drain Type-B installed at spacings of $1.1 \mathrm{~m}$ (WD5B) and $1.2 \mathrm{~m}$ (WD5A) provided similar DOC as Band Drain Type-A, despite Band Drain Type B being one of the most economical brand band drains on the market and significantly less costly than Band Drain Type A.

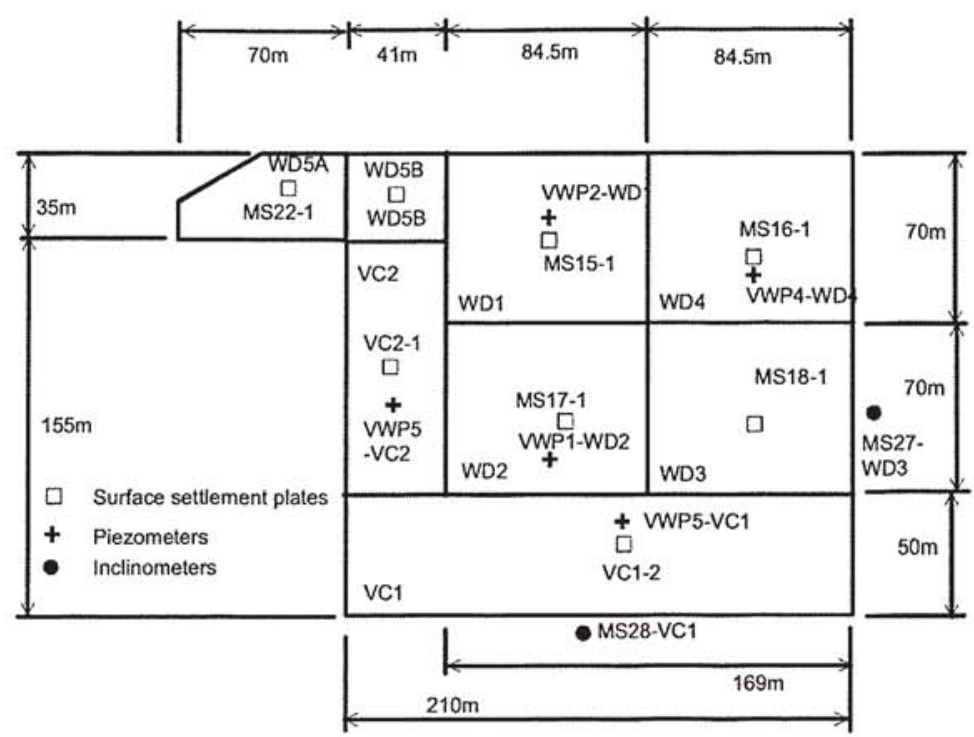

FIG 3. . Site layout for S3A with instrumentation plan, Port of Brisbane

TABLE 2. Degree of consolidation for various sections (data source: Indraratna et al. 2011)

\begin{tabular}{ccc}
\hline Sections & Drain type & $\begin{array}{c}\text { Calculated degree of consolidation after 400 } \\
\text { days (Strain-based, \%) }\end{array}$ \\
\hline WD1 & Circular drains & 92 \\
WD2 & Circular drains & 82 \\
WD3 & Band drain-A & 87 \\
WD4 & Band drains-A & 85 \\
WD5A & Band drains-B & 94 \\
WD5B & Band drains-B & 92 \\
VC1 & Circular drains & 87 \\
VC2 & Circular drains & 90 \\
\hline
\end{tabular}


A comprehensive picture of the effect of surcharge loading on the development of excess pore water pressure is shown in Fig. 4c. VC1 and VC2 showed the highest rates of excess pore pressure dissipation compared to the surcharge only areas. While the height of the fill was lower in the vacuum areas, the applied suction $(-70 \mathrm{kPa})$ increased the rate at which excess pore pressure dissipated, which confirmed the effectiveness of the vacuum consolidation technique.

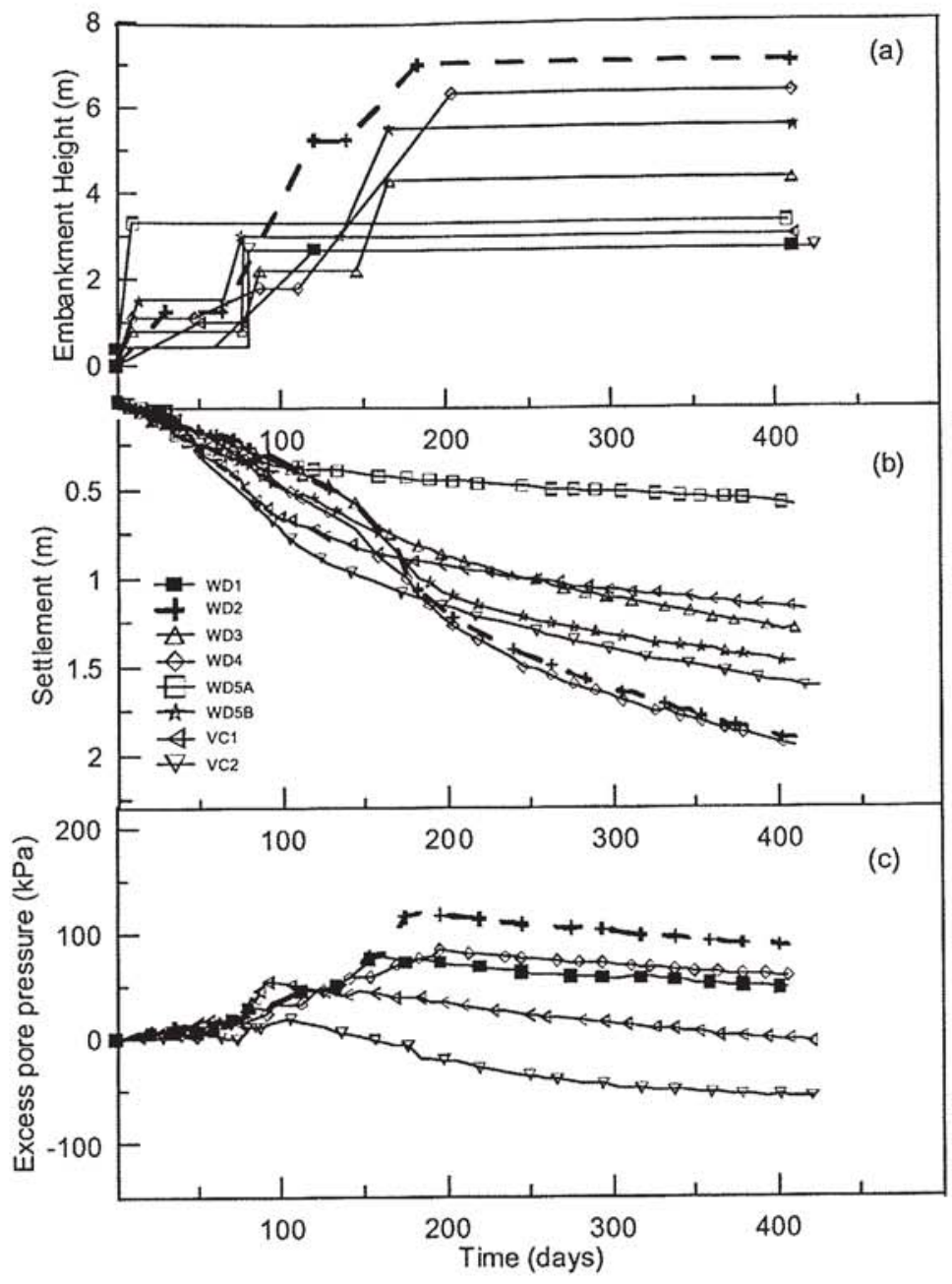

FIG 4. Embankment responses (a) staged construction, (b) settlements and (c) excess pore pressures (source data: Indraratna et al. 2011)

The measured horizontal displacements normalised to the total change in applied stress (vacuum plus surcharge load) for two locations (VC1/MS28 and WD3/MS27) are shown in Fig. 5. In the VC1 and WD3 areas, the total embankment load on the surface was similar. The largest normalised lateral displacements were within the layer of Lower Holocene clay, and were smallest in the layer of Holocene sand because of its greater stiffness. These plots indicate that the lateral movements were reduced by vacuum application. This reduction in lateral displacement with vacuumassisted consolidation has also been reported by Indraratna et al. (2005). 


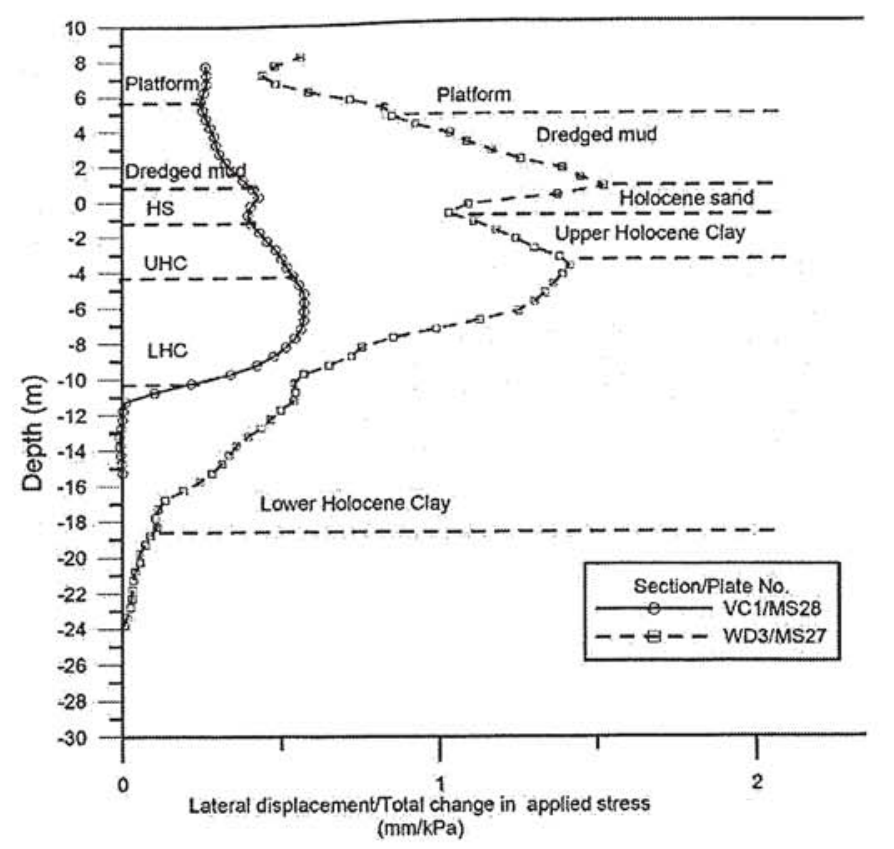

FIG 5. A comparison of lateral displacement at the embankment toe in the vacuum and non-vacuum area after $\mathbf{4 0 0}$ days (data source: Indraratna et al. 2011)

In this Section, an analytical model for vacuum consolidation is proposed where the ramp loading is considered: i.e., the embankment load at a given time $\left(\sigma_{t}\right)$ increases linearly with time up to a maximum value $\left(\sigma_{l}\right)$ at time $t_{0}$. A vacuum is applied at $t=t_{v a c}$. Following the procedure proposed by Lekha et al. (1998), Indraratna et al. (2011) proposed that the excess pore pressure due to radial consolidation while considering the smear effect under a time-dependent surcharge can be expressed by:

$\overline{u_{L}}=\frac{\mu d_{e}^{2}}{8 c_{h} t_{0}}\left(1-\exp \left(\frac{-8 c_{h} t}{\mu d_{e}^{2}}\right)\right) \sigma_{1} \quad$ for $\quad 0 \leq t \leq t_{0}$

$\overline{u_{L}}=\frac{\mu d_{e}^{2}}{8 c_{h} t_{0}}\left(1-\exp \left(\frac{-8 c_{h} t_{0}}{\mu d_{e}^{2}}\right) \exp \left(\frac{-8 c_{h}\left(t-t_{0}\right)}{\mu d_{e}^{2}}\right)\right) \sigma_{1}$ for $t>t_{0}$

Recently, Indraratna et al. (2005) showed that excess pore pressure under radial consolidation due to vacuum pressure alone could be determined from:

$$
\begin{aligned}
& u_{v a c}=0, \\
& u_{v a c}=p_{0} \exp \left(-\frac{-8 c_{h}\left(t-t_{v a c}\right)}{\mu d_{e}^{2}}\right)-p_{0}, \quad t \geq t_{v a c} \\
& \mu=\left[\ln \left(\frac{n}{s}\right)+\frac{k_{h}}{k_{s}} \ln (s)-\frac{3}{4}+\pi \frac{2 k_{h}}{3 q_{w}} l^{2}\right]
\end{aligned}
$$


$n=d_{e} / d_{w}$

$$
s=d_{s} / d_{w}
$$

where $d_{e}=$ the diameter of the soil cylinder de-watered by a drain, $d_{s}=$ the diameter of the smear zone, $d_{w}=$ the equivalent diameter of the drain, $k_{s}=$ horizontal soil permeability in the smear zone and $q_{w}=$ drain discharge capacity.

Figure 6 shows the calculated settlements and associated excess pore pressures with the measured data in Area VC2 where a total load of 120-130kPa was applied to a clay that was $20-23 \mathrm{~m}$ thick. Overall, the comparisons between prediction and field observation show that the settlement and associated pore water pressure can be reasonably predicted.

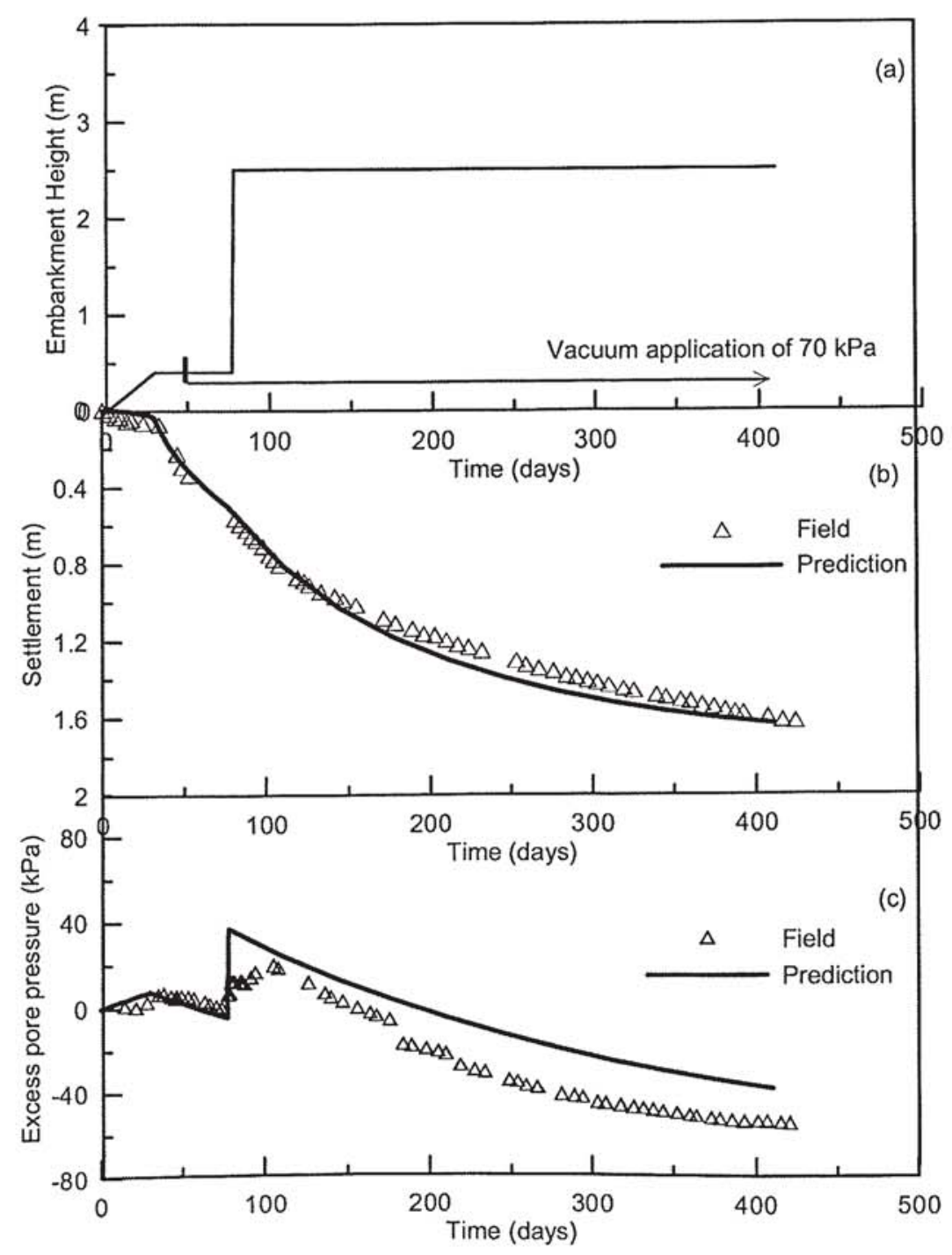

FIG 6. VC2 area: (a) loading stages, (b) surface settlements at embankment centerline and (c) excess pore pressures (data source: Indraratna et al. 2011) 


\section{CONCLUSIONS}

A system of vertical drains with vacuum preloading is an effective method for accelerating soil consolidation. The performance of reclaimed and consolidated ground at the Port of Brisbane was analysed and discussed. A total of 8 sub-areas were selected to examine the behaviour of vacuum consolidation and the influence of drain spacing and types of drains. A membrane type vacuum consolidation system with an array of monitoring instrumentation, including settlements, piezometers, and inclinometers was applied such that the average degree of consolidation attained was more than $85 \%$ after one year. In the surcharge only areas, both band PVDs and circular PVDs provided a similar performance.

In terms of drain spacing, 1.2-1.3 $\mathrm{m}$ was found to be sufficient for the design at this site. The data suggests that excessive soil disturbance offset the potential benefits of closer vertical drain spacing. The rate of excess pore pressure dissipation in the vacuum area was significantly higher than the non-vacuum areas, indicating that the vacuum pressure increased the lateral hydraulic gradient which promotes radial flow. When a vacuum pressure combined with a surcharge fill is adopted, the overall outward lateral movement can be reduced. This reduced lateral movement decreases shearing of the soil which increases the embankment's stability.

The unit cell theory considering a time-dependent surcharge load and vacuum application was proposed to predict the settlement and associated excess pore pressure, both of which agreed with the field measurements. A system of PVDs subjected to a combined vacuum surcharge preloading is a useful method for accelerating radial consolidation and controlling lateral displacement. The analytical model discussed here is a useful tool for predicting the performance of soft clay stabilized by PVDs.

\section{ACKNOWLEDGEMENTS}

The writers appreciate the support of the Port of Brisbane Corporation, Coffey Geotechnics and Austress Menard. The authors are particularly grateful to Dr. Jayantha Ameratunga and Peter Boyle for their assistance with field data. The research funding provided by the Australia Research Council is acknowledged. The assistance of Daniel Berthier of Austress Menard Bachy, Prof Harry Poulos, Cynthia De Bok, Tine Birkemose and Chamari Bamunawita of Coffey Geotechnics is also appreciated. More elaborate details of the contents discussed in the paper can also be found in previous publications of the first Author and his research students in ASCE and Canadian Geotechnical Journals, since the mid 1990's.

\section{REFERENCES}

Ameratunga, J., Boyle, P., De Bok, C. and Bamunawita, C. (2010). "Port of Brisbane (PoB) Clay Characteristics and Use of Wick Drains to Improve Deep Soft Clay Deposits." Proceedings 17th Asian Geotechnical Conference, Taipei, Vol I, pp 116-119. 
Austress Menard (2008). "Personal communication internal report and confidential." $79 \mathrm{p}$.

Berthier, D., Boyle, P., Ameratunga, J., De Bok, C. and Vincent, P. (2009). "A successful trial of vacuum consolidation at in the Port of Brisbane." PIANC 2009, Christchurch, New Zealand (in CD).

Chai, J.C., Carter, J.P., and Hayashi, S. (2005). "Ground deformation induced by vacuum consolidation." Journal of Geotechnical and Geoenvironmental Engineering, 131(12):1552-1561.

Chu, J. Yan, S.W., and Yang, H. 2000. "Soil improvement by the vacuum preloading method for an oil storage station." Géotechnique, 50(6): 625-632.

Geng, X. Y., Indraratna, B. and Rujikiatkamjorn, C. (2011). "Analytical solutions for a single vertical drain with vacuum and time-dependent surcharge preloading in membrane and membraneless systems." International Journal of Geomechanics, ASCE, (Accepted December 2011).

Holtz, R. D., Jamiolkowski, M., Lancellotta, R. and Pedroni, S. (1991). "Prefabricated vertical drains: design and performance." CIRIA ground engineering report: ground improvement. Butterworth-Heinemann Ltd, UK, 131.

Indraratna, B. and Redana, I. W. (2000). "Numerical modeling of vertical drains with smear and well resistance installed in soft clay." Canadian Geotechnical Journal, 37: 132-145.

Indraratna, B., Balasubramaniam, A.S. and Sivaneswaran (1997). "Analysis of Settlements and Lateral Deformation of Soft Clay Foundation beneath Two Embankments." International Journal of Numerical and Analytical Methods in Geomechanics, 31(9): 599-618.

Indraratna, B., Sathananthan, I., Rujikiatkamjorn C. and Balasubramaniam, A. S. (2005). "Analytical and numerical modelling of soft soil stabilized by PVD incorporating vacuum preloading." International Journal of Geomechanics, 5(2). 114-124.

Indraratna, B., Rujikiatkamjorn, C., Ameratunga, J., and Boyle, P. (2011) "Performance and Prediction of Vacuum Combined Surcharge Consolidation at Port of Brisbane." J. of Geotechnical \& Geoenvironmental Engineering, ASCE (Accepted in January 2011).

Lekha, K.R., Krishnaswamy, N.R., Basak, P. (1998). "Consolidation of clay by sand drain under time-dependent loading." J. Geotech. Engng., ASCE, 124(1), 91-94.

Mohamedelhassan, E., and Shang, J.Q. (2002). "Vacuum and surcharge combined one-dimensional consolidation of clay soils." Can. Geotech. J. 39: 1126-1138.

Port of Brisbane Corporation (2009). Annual report 2008/2009. Port of Brisbane Corporation, Brisbane, Queensland, 92p.

Rujikiatkamjorn, C., Indraratna, B. and Chu, J. 2008. "2D and 3D numerical modeling of combined surcharge and vacuum preloading with vertical drains." International Journal of Geomechanics, 8(2): 144-156.

Shang, J.Q., Tang, M., and Miao, Z. (1998). "Vacuum preloading consolidation of reclaimed land: a case study." Canadian Geotechnical Journal, 35: 740-749.

Yan, S.W. and Chu, J. (2003). "Soil improvement for a road using a vacuum preloading method." Ground Improvement, 7(4): 165-172. 